\title{
Simultaneous presentation of thyrotoxic crisis and diabetic ketoacidosis
}

\author{
J. F. BRIDGMAN \\ M.B., M.R.C.P.
}

S. Pett

M.B. B.S.

Orsett Hospital, Grays, Essex

\begin{abstract}
Summary
Two patients presented with co-existing development of diabetic ketoacidosis and thyrotoxic crisis. The difficulties of diagnosis and management of such cases are discussed.
\end{abstract}

\section{Introduction}

The combination of diabetes mellitus with thyrotoxicosis is well known and one condition usually precedes the other (Wilder, 1926) but the co-existence of diabetic ketoacidosis and thyrotoxic crisis is rare (Hanscom and Ryan, 1957). Two cases are described where these serious complications occurred simultaneously as the presenting features and provided difficulties in diagnosis and management.

\section{Case reports}

\section{Case 1}

An 18-year-old female presented with a 2-day history of generalized abdominal pain and vomiting. For one week she complained of polyuria and polydipsia. There was a pyrexia of $40^{\circ} \mathrm{C}$, she was semi-comatose, dehydrated and ketoacidotic. The pulse was 180 sinus rhythm and the BP $80 / 60 \mathrm{mmHg}$. There was generalized guarding and tenderness of the abdomen with absent bowel sounds. The results of the serum electrolytes showed a sodium 135 $\mathrm{mmol} / \mathrm{l}$, potassium $2.6 \mathrm{mmol} / \mathrm{l}$, chloride $75 \mathrm{mmol} / \mathrm{l}$, bicarbonate $6 \mathrm{mmol} / \mathrm{l}$, urea $5 \mathrm{mmol} / \mathrm{l}(30 \mathrm{mg} / \mathrm{dl})$, and glucose $24 \mathrm{mmol} / \mathrm{l}(412 \mathrm{mg} / \mathrm{dl})$. Treatment was commenced with i.v. fluids and insulin. After $12 \mathrm{hr}$ the results of the serum electrolytes showed a sodium of $140 \mathrm{mmol} / \mathrm{l}$, potassium $4.6 \mathrm{mmol} / \mathrm{l}$, chloride $105 \mathrm{mmol} / \mathrm{l}$, bicarbonate $14 \mathrm{mmol} / \mathrm{l}$ and glucose $12 \mathrm{mmol} / \mathrm{l}(216 \mathrm{mg} / \mathrm{dl})$. However, there was no significant improvement in her general condition and the physical signs remained unchanged. At this stage a laparotomy was carried out.

At laparotomy fresh, clear, free fluid with enlargement of the mesenteric lymph nodes was found. Postoperatively she developed signs of meningism, the CSF showed a slight increase in the lymphocyteo count but was under normal pressure. She also. developed a supraventricular tachycardia with a rateo of $260 / \mathrm{min}$ which responded to i.v. practolol andis digoxin reducing the rate to $120 / \mathrm{min}$. The following day, a goitre and bilateral exophthalmos had

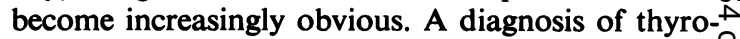
toxic crisis was made and treatment commenced with propranolol, carbimazole and potassium iodide $\overrightarrow{-}$ given via a nasogastric tube, in conjunction with continuous i.v. fluids and insulin. Within $24 \mathrm{hr}$ her general condition had improved dramaticalty. Further investigations are illustrated in the tabes. After 6 months her thyrotoxicosis had gone infor remission and her diabetes was well controlled ongas twice daily combination of soluble and isophane insulin.

\section{Case 2}

A 31-year-old female, gave a 3-week history of weight loss, thirst and polyuria. For 2 days before admission to hospital she complained of persistent vomiting and generalized abdominal pain. On examination she was extremely restless, dehydrated, 3 ketoacidotic with a pyrexia of $40^{\circ} \mathrm{C}$. The BP wasi$100 / 60 \mathrm{mmHg}$ and a pulse rate of 160 sinus rhythm. There was a well marked exophthalmos, an enlarged thyroid with an associated bruit. The blood glucose 3 was $24 \mathrm{mmol} / \mathrm{l}(412 \mathrm{mg} / \mathrm{dl})$ and the bicarbonateo $4 \mathrm{mmol} / \mathrm{l}$.

She was treated with i.v. fluids and insulin. Pro- $-\frac{D}{2}$ pranolol, carbimazole and potassium iodide were given via a nasogastric tube. Within $48 \mathrm{hr}$ her generalo condition had improved significantly. Further in- $N$ vestigations are shown in the table.

One year since her presentation she remains on ${ }_{\sigma}$ conventional anti-thyroid drugs and a twice daily combination of soluble and isophane insulin. $A \stackrel{-}{\complement}$ Synacthen test of adrenal function remains normal. $\stackrel{+}{+}$

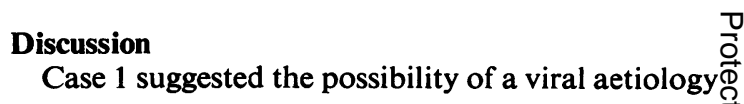


TABLE 1. Results of investigations

\begin{tabular}{|c|c|c|c|c|}
\hline & \multicolumn{2}{|c|}{ Case 1} & \multicolumn{2}{|c|}{ Case 2} \\
\hline Serum thyroxine (normal range $53-160 \mathrm{nmol} / \mathrm{l}$ ) & \multicolumn{2}{|c|}{$205 \mathrm{nmol} / 1$} & \multicolumn{2}{|c|}{$210 \mathrm{nmol} / 1$} \\
\hline Free thyrotoxine index (normal range $45-150$ ) & \multicolumn{2}{|c|}{305} & \multicolumn{2}{|c|}{220} \\
\hline $\begin{array}{l}\text { Autoantibodies } \\
\text { Thyroid - Thyroglobulin } \\
\text { Colloid } \\
\text { Cytoplasmic }\end{array}$ & & & & \\
\hline Islet cell & \multicolumn{2}{|c|}{-} & \multicolumn{2}{|c|}{+++} \\
\hline Adrenal & \multicolumn{2}{|c|}{-} & \multicolumn{2}{|c|}{+++} \\
\hline Gastric parietal cell & \multicolumn{2}{|c|}{-} & \multicolumn{2}{|c|}{+++} \\
\hline \multirow[t]{2}{*}{ HLA antigens } & \multicolumn{2}{|c|}{$\begin{array}{l}\text { A2.AW26. } \\
\text { B13.BW40. }\end{array}$} & \multicolumn{2}{|c|}{ A1.A2.B8. } \\
\hline & \multicolumn{2}{|c|}{ Sera } & \multicolumn{2}{|c|}{ Sera } \\
\hline $\begin{array}{l}\text { Virology } \\
\text { Coxsackie titres } \\
\qquad \begin{array}{c}\text { B2 } \\
\text { B4 } \\
\text { B5 }\end{array}\end{array}$ & $\begin{array}{l}40 \\
20 \\
40\end{array}$ & $\begin{array}{l}80 \\
20 \\
80\end{array}$ & $\begin{array}{r}32 \\
128 \\
12\end{array}$ & $\begin{array}{r}64 \\
256 \\
12\end{array}$ \\
\hline
\end{tabular}

because of the associated meningoencephalitis and mesenteric lymphadenitis, but it was not possible to confirm this assumption. However, Case 2 showed a rising titre to Coxsackie B2 and B4. A combination of an infection with Coxsackie B4 virus, the HLA type B8 and high titres of islet cell antibodies have been implicated in the aetiology of insulin-dependent diabetes (Gamble, 1974; Morris et al., 1976) and these features were found in Case 2. Furthermore, there is an association of this particular HLA type with thyrotoxicosis (Grumet et al., 1974) and in Case 2 there was also a striking autoantibody response to the thyroid, adrenal and stomach but these features were not apparent in Case 1. In these patients, it is not evident if one condition preceded or precipitated the other, because both had an acute fulminating presentation and furthermore the diabetic ketoacidosis may obscure the thyrotoxic crisis.

Thyrotoxicosis can produce vomiting (Rosenthal, Jones and Lewis, 1976) and diabetic ketoacidosis is a well known cause of abdominal pain and vomiting.
Clearly, although the surgeon may be well aware of the diabetic ketoacidosis, thyrotoxicosis must also be considered in the differential diagnosis, thus avoiding the difficulties in the management that were apparent in Case 1.

\section{References}

GAMBLE, D.R. (1974) Epidemiological and virological observations on juvenile diabetes. Postgraduate Medical Journal, 50, 538.

Grumet, F.C., PAYNe, R.O., Konishi, J. \& KRISS, J.P. (1974) HLA antigens as markers for disease susceptibility and autoimmunity in Graves' disease. Journal of Clinical Endocrinology and Metabolism. 39, 1115.

HaNSCOM, D.H. \& RYAN, R.J. (1957) Thyrotoxic crisis and diabetic ketoacidosis. New England Journal of Medicine, 257, 697.

Morris, P.J., Irvine, W.J., Gray, R.S., Duncan, L.J.P., Vaughan, H., McCallum, F.J., Campbell, C.J. \& FARQUHAR, J.W. (1976) HLA and pancreatic islet cell antibodies in diabetes. Lancet, ii, 652.

Rosenthal, F.D., Jones, C., Lewis, S.I. (1976) Thyrotoxic vomiting. British Medical Journal, 2, 209.

WILDER, R. (1926) Hyperthyroidism, myxedema and diabetes. Archives of Internal Medicine, 38, 736. 